\section{Small-Cell Carcinoma of the Cervix at 23 Weeks Gestation}

A 26-year-old primigravida with no significant past medical history presented at 23 weeks gestation with a history of a watery vaginal discharge of 1 month's duration. Speculum examination revealed a polypoid mass in the cervix. Magnetic resonance imaging (MRI) of the lesion showed a large, exophytic, macrolobulated mass surrounding the cervix and distending the vagina measuring $9.4 \times 4.6 \times 9 \mathrm{~cm}$. It did not appear to invade the adjacent fat or vaginal wall (Fig 1). MRI of the abdomen showed a normal liver and no evidence of retroperitoneal or paraortic lymphadenopathy. Low-dose computed tomography of the thorax showed normal lung fields and mediastinum, and no sclerotic or lytic bony lesions. After a biopsy, the mass was shown to consist of sheets of small, densely packed cells, with hyperchromatic nuclei and a high nuclear-to-cytoplasmic ratio consistent with a small-cell carcinoma (Fig 2). Neuroendocrine origin was confirmed with staining for synaptophysin (Fig 3) and chromogranin (Fig 4). A diagnosis of small-cell carcinoma of the cervix in association with pregnancy was made. As the patient wished to maintain her pregnancy and was at 23 weeks gestation, a decision was made to proceed with neoadjuvant chemotherapy with adriamycin $\left(60 \mathrm{mg} / \mathrm{m}^{2}\right)$ and cyclophosphamide $\left(600 \mathrm{mg} / \mathrm{m}^{2}\right)$ intravenously every 21 days, which was given for three cycles without adverse effects. Repeat MRI

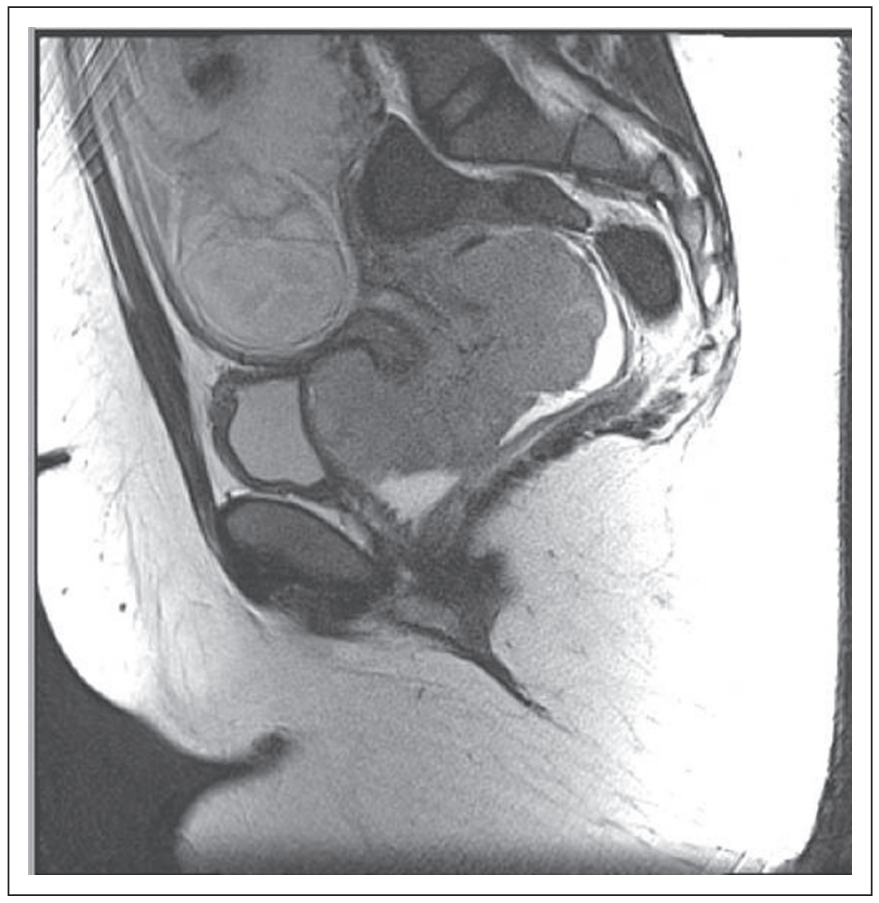

Fig 1.

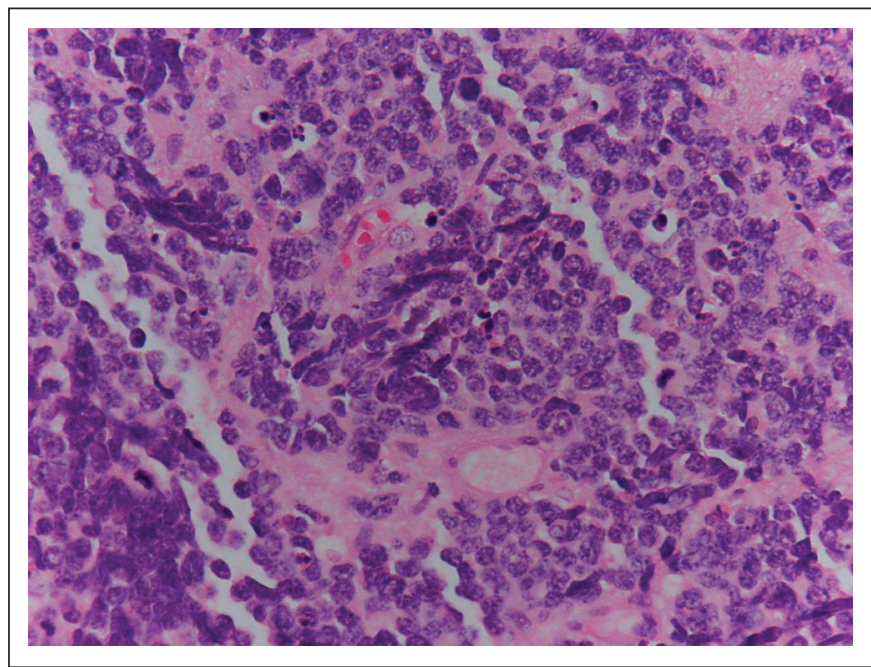

Fig 2.

showed a significant decrease in tumor volume by $85 \%$ with a maximum tumor diameter of $2.8 \mathrm{~cm}$ (Fig 5). This was confirmed on clinical examination. A fourth cycle of chemotherapy was deferred due to the onset of mild intrauterine growth retardation in the fetus. The patient underwent delivery of a healthy 6-pound baby boy by elective Caesarian section at 35 weeks gestation. After delivery, the patient subsequently underwent four cycles of platinum and etoposide-based chemotherapy with good clinical and radiologic response in the pelvis and showing no evidence of metastatic spread. She is currently undergoing definitive local treatment with pelvic radiation.

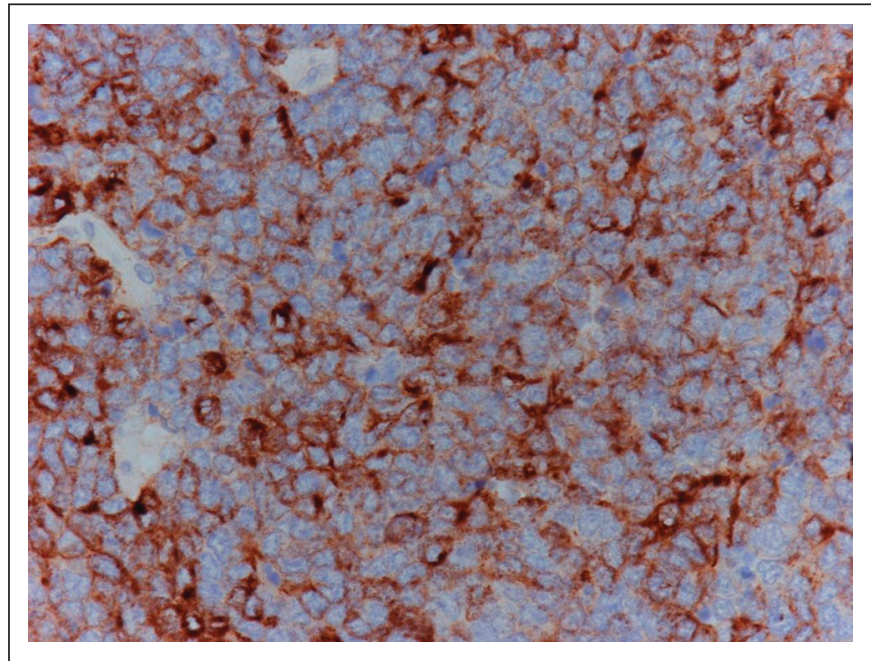

Fig 3. 


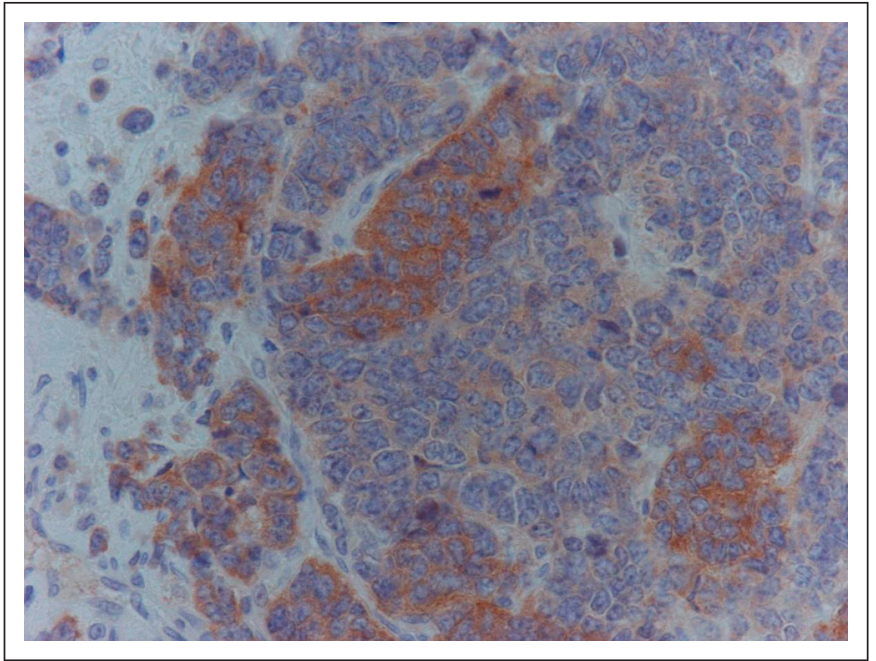

Fig 4.

Neuroendocrine tumors of the cervix are rare, accounting for fewer than $2 \%$ of all cervical malignancies. The most common of these is small-cell cancer of the cervix, the mean annual incidence of which is 0.06 per 100,000 women, compared with 6.6 per 100,000 women for squamous cell carcinoma. ${ }^{1}$ Small-cell carcinoma of the cervix behaves in a similar manner to small-cell lung carcinoma, with vascular invasion common, and death most likely due to hematogenous spread and distant metastases. ${ }^{2}$ Three-year overall survival ranges from $29 \%$ to $60 \%$ in series with multimodality therapy with the highest survival in those treated with combined chemotherapy and local treatment (eg, surgery, radiation, or both) ${ }^{3-5}$ Neuroendocrine tumors of the cervix occurring during pregnancy are extremely rare, with a small number of cases reported in the literature. ${ }^{6-10}$ This patient presented at 23 weeks

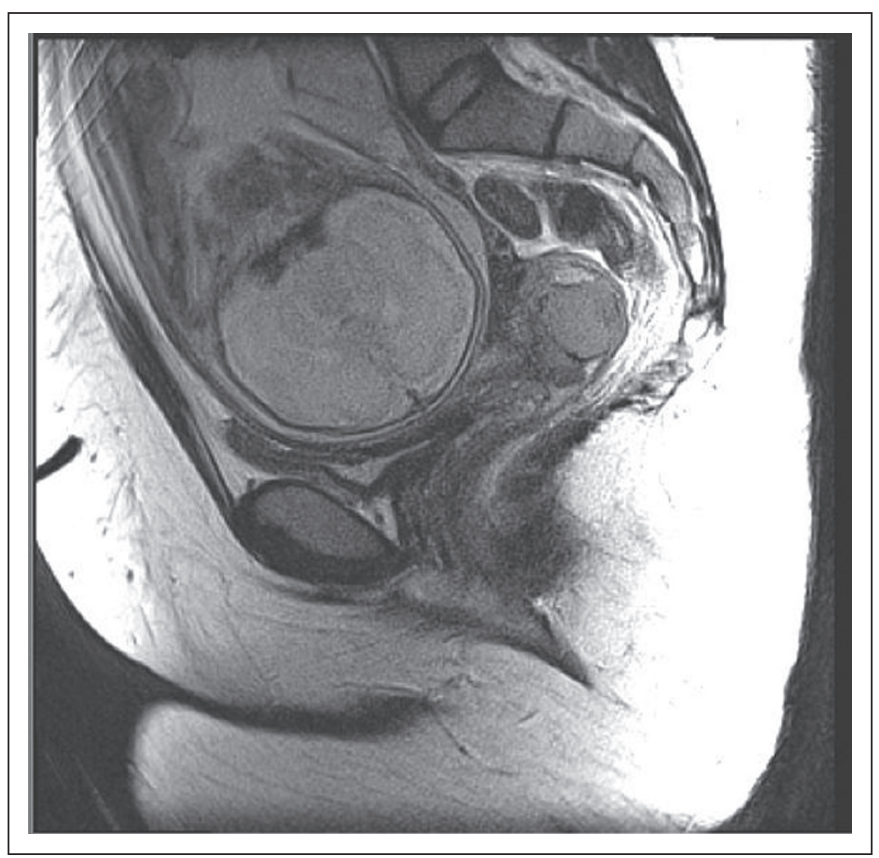

Fig 5. gestation and wished to continue with her pregnancy. The most commonly used drugs in small-cell carcinoma are platinum compounds and etoposide. There exists only limited evidence for the safe use of these drugs in pregnancy. ${ }^{11-14}$ However, adriamycin and cyclophosphamide, as the major components of the regimen vincristine, adriamycin, and cyclophosphamide have comparable efficacy in the treatment of small-cell lung carcinoma when compared with the platinum and etoposide regimen. ${ }^{15}$ There is also significant experience in the use of these agents as the adriamycin and cyclophosphamide regimen in pregnant women who are diagnosed with breast cancer. This regimen may be given safely with no short- or long-term effects to the fetus once the mother has reached the second trimester of pregnancy. ${ }^{16-18}$ This case illustrates some of the complexities of cancer diagnosis, staging, and treatment during pregnancy, in addition to the successful treatment of a small-cell carcinoma of the cervix with two sequential chemotherapy regimens.

Elizabeth C. Smyth, Grzegorz Korpanty, John A. McCaffrey, Niall Mulligan, and Desmond N. Carney

Mater Misericordiae University Hospital, Dublin, Ireland

\section{AUTHORS' DISCLOSURES OF POTENTIAL CONFLICTS OF INTEREST}

The author(s) indicated no potential conflicts of interest.

\section{REFERENCES}

1. Chen J, Macdonald OK, Gaffney DK, et al: Incidence, mortality and prognostic factors of small cell carcinoma of the cervix. Obstet Gynaecol 111:1394-1402, 2008 Jun

2. Viswanathan $A N$, Jhingran $A$, Deavers $M T$, et al: Patterns of failure in small cell carcinoma of the cervix. Int J Radiat Oncol Biol Phys 54:51, 2002 (suppl 41)

3. Zivanovic O, Leitao Jr MM, Park KJ, et al: Small cell neuroendocrine carcinoma of the cervix: Analysis of outcome, recurrence pattern and the impact of platinum-based combination chemotherapy. Gynecol Oncol 112:590-593, 2009

4. Viswanathan AN, Deavers MT, Jhingran A, et al: Small cell neuroendocrine carcinoma of the cervix: Outcome and patterns of recurrence. Gynecol Oncol 93:27-33, 2004

5. Hoskins PJ, Swenerton KD, Pike JA, et al: Small-cell carcinoma of the cervix: Fourteen years of experience at a single institution using a combinedmodality regimen of involved-field irradiation and platinum-based combination chemotherapy. J Clin Oncol 21:3495-3501, 2003

6. Punnonen R, Ekfors T, Groenroos M: Pregnancy and small cell carcinoma of the uterine cervix. Ann Chir Gynaecol 68:20-22, 1979

7. Chang DH, Hsueh S, Soong YK: Small cell carcinoma of the uterine cervix with neurosecretory granules associated with pregnancy: A case report. J Reprod Med 39:537-540, 1994

8. Balderston KD, Tewari K, Gregory WT, et al: Neuroendocrine small cell uterine cervix cancer in pregnancy: Long-term survival following combined therapy. Gynecol Oncol 71:128-132, 1998

9. Leung TW, Lo SH, Wong SF, et al: Small cell carcinoma of the cervix complicated by pregnancy. Clin Oncol (R Coll Radiol) 11:123-125, 1999

10. Ohwada M, Suzuki $M$, Hironaka $M$, et al: Neuroendocrine small cell carcinoma of the uterine cervix showing polypoid growth and complicated by pregnancy. Gynecol Oncol 81:117-119, 2001

11. King LA, Nevin PC, Williams PP, et al: Treatment of advanced epithelial ovarian carcinoma in pregnancy with cisplatin-based chemotherapy. Gynecol Oncol 41:78-80, 1991

12. Ohara $N$, Teramoto $K$ : Successful treatment of an advanced ovarian serous cystadenocarcinoma in pregnancy with cisplatin, adriamycin and cyclophosphamide (CAP) regimen: Case report. Clin Exp Obstet Gynecol 27:123-124, 2000

13. Han JY, Nava-Ocampo AA, Kim TJ, et al: Pregnancy outcome after prenatal exposure to bleomycin, etoposide and cisplatin for malignant ovarian germ cell tumors: Report of 2 cases. Reprod Toxicol 19:557-561, 2005 
14. Karam A, Feldman $\mathrm{N}$, Holschneider $\mathrm{CH}$ : Neoadjuvant cisplatin and radical cesarean hysterectomy for cervical cancer in pregnancy. Nat Clin Pract Oncol 4:375-380, 2007

15. Fukuoka M, Furuse K, Saijo N, et al: Randomized trial of cyclophosphamide, doxorubicin, and vincristine versus cisplatin and etoposide versus alternation of these regimens in small-cell lung cancer. J Natl Cancer Inst 83:855-861, 1991

16. Berry DL, Theriault RL, Holmes FA, et al: Management of breast cancer during pregnancy using a standardized protocol. J Clin Oncol 17:855-861, 1999
17. Ring $A E$, Smith $I E$, Jones $A$, et al: Chemotherapy for breast cancer during pregnancy: An 18-year experience from five London teaching hospitals. J Clin Oncol 23:4192-4197, 2005

18. Hahn KM, Johnson $\mathrm{PH}$, Gordon $\mathrm{N}$, et al: Treatment of pregnant breast cancer patients and outcomes of children exposed to chemotherapy in utero. Cancer 107:1219-1226, 2006

DOI: 10.1200/JCO.2009.25.5604; published online ahead of print at www.jco.org on April 12, 2010 